\title{
e-Pedagogy: the pedagogies of e-learning
}

\author{
Wassila Naamani Mehanna* \\ University of Cambridge, UK
}

The aim of this research was to establish effective e-learning practice in higher education. This was achieved by looking at examples of different pedagogic techniques employed in several cases. The effectiveness of these techniques was established by looking at the students' outcomes on these courses. This study has adopted a sequential mixed methodology characterized by an initial phase of qualitative data collection and analysis, which was followed by a phase of quantitative data collection and analysis. The first phase of the study involved collecting a year of data from a postgraduate programme. A grounded approach was used to analyse one million words of online conferences or discussions, and led to the emergence of 29 pedagogic behaviours. These pedagogic behaviours were then developed into a coding instrument. The second phase, hypothetico-deductive analysis, confirmed their presence in three other cases, five million words of online interactions, and established their associations with students' learning and outcomes. The findings suggest seven clusters of pedagogies correlated with students' grades and the effect size calculation revealed an educational significance for all of them. This indicates that if they are employed in online classrooms they are likely to enhance students' learning and outcomes.

\section{Introduction}

Despite an increased interest in the use of e-learning to enhance students' learning, it is surprising that so little research has been conducted to justify these claims. Goodyear (2001) concluded: 'the literature on learning in higher education is surprisingly quiet with respect to what both lay people and practitioners might expect to be a key construct - that of "understanding", (p. 62). Another confirmation was put forward by Spector (2002), who reported: 'the big lesson about technology and learning from the $20^{\text {th }}$ century is that less is known about how people learn than many educational researchers are inclined to admit' (p. xiv). It is therefore critical to find out how effective e-learning practices are achieved.

\footnotetext{
*Faculty of Education, University of Cambridge, 17 Trumpington Street, Cambridge CB2 1QA, UK. Email:wm212@cam.ac.uk
} 
In their review of 100 published research reports completed in the period 19912001, Coomey and Stephenson (2001) found little if any definitive evidence of the overall effectiveness of 'e-learning' compared with more conventional methods. This is not to say that this medium is ineffective but rather to say that there is little systematic and empirical work to show evidence of its evaluation. Laurillard (2002) added that we may not have an established set of characteristic forms of effective e-learning; however, we could identify some effective existing learning activities and produce a model that captures the good practices embedded in the activity regardless of the tool utilized. As a result, if we are to unravel the various components of effective e-learning practice, we need to consider pedagogy. Pedagogies are connected with students' learning and outcomes, and have been widely accepted for epistemological and empirical reasons. In this way, the issue of integrating e-learning into the pedagogical system has recently emerged as an important and pressing focus for research.

While much has been said about the failure of research to provide adequate analytical frameworks for studying e-pedagogy, few researchers have referred to certain practices that promote effective learning. Recommendations in the literature point towards technologies specifically designed to provide interactivity that guides students towards online collaborations (Crook, 1994). This in turn promotes, among other things, skills such as articulation, justification and negotiation (Crook, 1994), shared responsibilities (Laurillard, 1997; Goodyear, 2001), scaffolding (Salmon, 2000), setting hypotheses (Valdez et al., 2000), reflection (Schon, 1992; Laurillard, 1997; Goodyear, 2002), knowledge activation and knowledge application (Gagne, 1965; Bruner, 1997a,b; Goodyear, 2001), individualized learning and motivation (Goodyear 2002; Garcia \& Pintrich, 1991, 1993, 1995), goal setting (Schon, 1992; Laurillard, 1993, 1997; Goodyear, 2001; Gagne, 1977), and characteristics such as positive attitude (Mehanna, 2002, 2004), and disposition (Gagne, 1977; Garcia \& Pintrich, 1991). All these are produced while students are engaging in cognitive, metacognitive and other learning systems. They have also to be complemented by tutors' strategies such as feedback and reflections (Schon, 1992; Laurillard, 1997).

While the new technologies may eventually lead us to develop a new understanding of effective pedagogies that are specific to these learning contexts, a good place to start is to look for well-established pedagogies that extant research tells us are effective in other teaching and learning contexts and tie in well with students' outcomes. However, a researcher trying to collect facts about what research has found about pedagogy is faced with a daunting task. For example, as cited in Marzano (1998), Hattie et al. (1996) identified over 21,000 studies that one would have to consult for a comprehensive literature review on the factors that affect students' outcomes and achievement in education. Looking for effective pedagogies in the meta-analyses research or 'evidenced-based research' that guided educational interventions seems a sensible starting point.

Following an extensive and systematic search of databases, Marzano's (1998) 'A theory-based meta-analysis of research on instructions' was identified as the most 
sophisticated and appropriate. It posited the interaction of four aspects or systems of human thought operating in most, if not all situations:

- The self-system processing of presenting tasks. This system contains a network of interrelated beliefs that enable one to make sense of the world (Markus \& Ruvulo, 1990) and processes that evaluate the importance of the presenting task relative to a system of goals and assesses the probability of success relative to the individual's beliefs. (Harter, 1980; Garcia \& Pintrich, 1991, 1993; Garcia, 1995). If the presenting task is judged as important and the rate of success is high, positive affect is generated and the individual is motivated to engage in the presenting task.

- The use of task-related knowledge. This system is comprised of the information, mental processes, and psychomotor processes that are specific to a subject matter (Ajzen, 1985; Ajzen \& Fishbein, 1977, 1980; Ajzen \& Madden, 1986).

- The cognitive processing of tasks is responsible for the effective processing of the information essential to the presenting task (Anderson, 1995). This system acts on an individual knowledge base (Lindsay \& Norman, 1977) and can be organized in four categories: storage and retrieval, information processing, input/output, and knowledge utilization (Marzano, 1998)

- The meta-cognitive processing of tasks controls any and all aspects of the knowledge and the cognitive system (Sternberg, 1977, 1979, 1984, 1986, 1986a, 1986b; Schank \& Abeleson, 1977). To this extent, this system has been described as responsible for the 'executive control of all processes' (Flavell, 1979, 1987; Brown, $1978,1987)$. In other words, it is the 'engine for learning' (Marzano, 1998).

Figure 1 summarizes Marzano's (2001) learning systems and their connections From these four systems, Marzano (2001) teased out nine specific pedagogies that were further researched in a separate meta-analysis (Marzano, 2000). Based on their effect sizes (ES) Marzano recommended their use by all teachers in all subject areas. They are:

- Identifying similarities and differences between items (ES $=1.61)$.

- Summarizing and note taking which involves at least two highly related elements: filling missing parts and translation of information into a synthesized form (ES = 1.00).

- Recognizing effort and providing recognition are strategies that deal with students' attitudes and beliefs and thus, are likely to affect students' level of engagement in cognitive processes $(\mathrm{ES}=0.80)$.

- Homework and practice provide students with opportunities to deepen their understanding and proficiency in any content area $(\mathrm{ES}=0.77)$.

- Nonlinguistic representations involve the use of graphs, charts, maps, mind maps $(\mathrm{ES}=0.75)$.

- Cooperative learning comprises five elements: positive interdependence, face-toface promotive interaction, individual and group accountability, interpersonal and small group skills, and group processing $(\mathrm{ES}=0.73)$.

- Generating and testing hypotheses involve the application of knowledge (ES = 0.61). For example, a student watches a demonstration on how air flows over the 


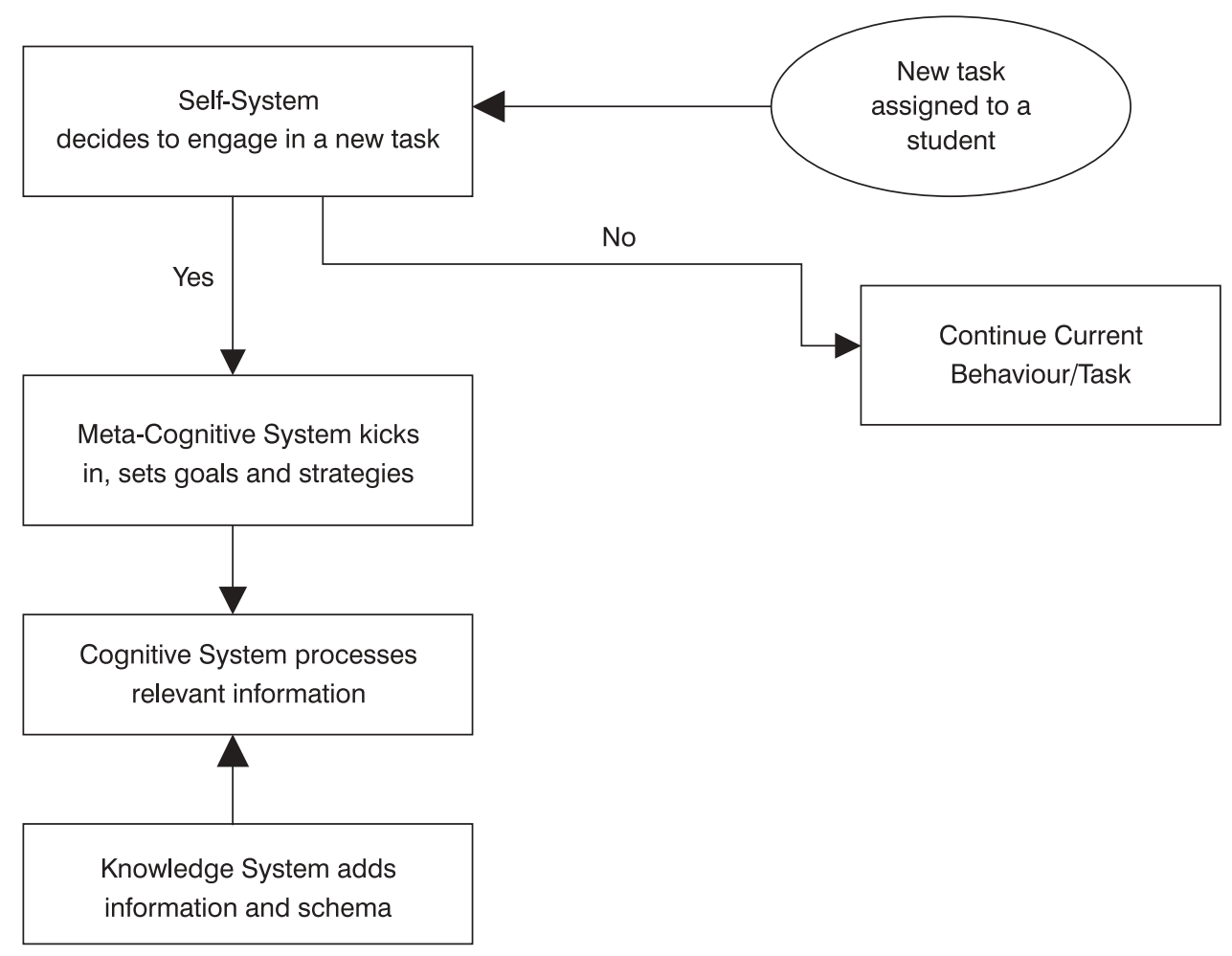

Figure 1. The four systems of learning and their connections

wing of a plane. Later, he applies this in hypothesizing that the changing shape of wings in a specific way will have a specific effect on the flow of air, designs a wing with desire shape and test his conjecture (Marzano, 1998).

- Setting objectives and providing feedback are activities that many researchers and theorists refer to as the meta-cognitive system of thinking. Both strategies were found to greatly enhance $(\mathrm{ES}=0.61)$.

- Activating Prior Knowledge. The tutor can help students use their background knowledge to learn new information is to present them with advance organizers such as questions and cues $(\mathrm{ES}=0.59)$.

The two meta-analyses provided us with evidence-based research that highlighted specific pedagogies and their association and impact on students' learning. It seems reasonably obvious that e-learning makes use of techniques that have been used effectively in face-to-face learning. However, this study wants the grounded analysis to reveal, in the first instance, the kind of strategies embedded in the online discussions.

Mortimore (1999) refers to pedagogy as a 'contested' term with 'changing connotations and pressures'. His preferred definition states that pedagogy is: 'any conscious action by one person designed to enhance learning in another' (p. 3). 
For the purpose of this study, pedagogy is any effective behaviour or activities designed to impart knowledge, it is used in the process of teaching and learning, and has an association with students' learning and outcomes. Of particular interest to many e-learning researchers have been those pedagogies associated with social interactions and online discussions (Henri, 1997; Stephenson, 2002; Alexander \& Boud, 2001). Online discussions are facilitated by Computer Conferencing, a web-based communication system that supports asynchronous, textual interaction between two or more persons. Online discussions combine input from tutors and students, and provide opportunities to examine their online interactions, which have been facilitated by the technology. Consequently, a great emphasis was placed on the written communications as they might reveal evidence of students' participation, contribution, communication and work that shows knowledge application, and criticality among other indicators of meaningful and effective learning. Moreover, tutors' input could be monitored for facilitation, feedback and other evidence of effective teaching.

Studies that have analysed the content of the online discussions were also limited. This is due to the time required to perform such analyses (Hara et al., 2000) and researchers still lack a reliable instrument or an analytical framework to analyse the online discussions. Goodyear (2001) noted: 'Analyzing the content of networked learning discussions is a troublesome research area and several commentators have remarked on the difficulty of connecting online texts to discourse to learning' (p. 62).

\section{Methodology}

A mixed-modal methodology was adopted using both quantitative and qualitative techniques. Using this approach not only helps answer certain research questions but also facilitates the triangulation within and between stages. Creswell's (2003) model of sequential exploratory procedures fit the purposes of this study. It is characterized by an initial phase of qualitative data collection and analysis, which is followed by a phase of quantitative data collection and analysis. 'Collective case studies' (Stake, 2000) were adopted to investigate several cases which are chosen because it is believed that understanding the collection will lead to understanding and better theorizing of a still larger collection of cases. Four postgraduate programmes in four different UK universities were purposively chosen. 200 students and 14 tutors took part in this study.

The processes of coding and analysis were iterative and started by sorting all online interactions according to individuals' postings. Each student and each tutor had a file. This data was then converted from HTML into text files in order to load it in NViVo.

The first stage of the study adopted a grounded approach. When the data was saturated, the end of phase one of the study had been reached, and stage two began with the development of the code schedule. The content analysis of stage two acted as a wider theoretical sample, for all the categories were re-visited in an attempt to disconfirm or qualify the findings. The researcher went over the transcript sentence by sentence and coded according to the existing twenty-nine categories. Once the coding 
was done, a summary sheet was completed for each student and tutor that included the occurrences or frequencies for each one of the pedagogies. Three inter-raters reliability checks were done and their average showed $95.7 \%$ agreements. The frequencies of these pedagogies along with students' grades were entered in SPSS for statistical compilations. To unify the measure, all frequencies were rescaled into percentages which facilitated the comparisons between students within the same group and across groups.

For triangulation, online questionnaires and interviews were administered to solicit students' and tutors' accounts with regard to the use of these 29 pedagogic behaviours and their occurrences in the online interactions.

\section{Findings}

The first stage of the research consisted of collection of a year of data from a postgraduate programme. A grounded approach was used to analyse one million words of online discussions. Twenty-nine strategies and pedagogic behaviours emerged from students-students and students-tutors interactions. They were categorized into three main groups to form the coding schedule: five common strategies for both students and tutors, thirteen strategies specific to tutors and eleven for students.

The code schedule was then implemented to test the presence of these pedagogic behaviours in three other cases and five million words of online interactions. The text of the online discussions was read sentence by sentence, and coded according to the coding schedule. As a result, the 29 pedagogic behaviours that have emerged from stage one were re-visited, re-interrogated, and re-confirmed in this stage. All categories were present and no new ones have emerged.

Strauss and Corbin (1998) noted that 'axial coding' may be used to relate categories and to continue to develop them in terms of their properties and dimensions until final classifications are reached and we could label the phenomena accordingly. An attempt was therefore made to group the 29 pedagogic behaviours into nine clusters that were theoretically and conceptually tied. The new clusters revealed striking compatibility with Marzano's nine and the 29 categories that emerged from this study provided detailed explanations for each cluster in the form of more specific strategies that could be embedded under each one of Marzano's. In addition to the triangulation achieved in this way, this clustering provided an opportunity to test Marzano's school-based theory in the context of on-line higher education. Table 1 shows the pedagogies, the clusters and their theoretical backing.

Seven clusters correlated with students' grades:

- Summarizing and note taking (with a correlation of $r(\mathrm{df}=138)=.287^{\star \star}, p<$ $0.001)$.

- Reinforcing Effort and Providing Recognition (with a correlation of $r(\mathrm{df}=138)=$ $\left..181^{\star \star}, p<0.02\right)$.

- Homework and practice (with a correlation of $\left.r(\mathrm{df}=138)=.487^{\star \star}, p<0.001\right)$.

- Non-Linguistic Presentation (with a correlation of $\left.r(\mathrm{df}=138)=.151^{\star \star}, \mathrm{p}<0.05\right)$. 
Table 1. Clusters, pedagogies and theoretical backing

\begin{tabular}{|c|c|c|c|}
\hline $\begin{array}{l}\text { Clusters according } \\
\text { to Marzano's } 9\end{array}$ & $\begin{array}{l}\text { The } 29 \text { pedagogic } \\
\text { behaviours }\end{array}$ & Type & Theoretical backing \\
\hline $\begin{array}{l}\text { Identifying } \\
\text { similarities and } \\
\text { differences }\end{array}$ & $\begin{array}{l}\text { - Comparison and } \\
\text { contrast } \\
\text { - Using analogies and } \\
\text { metaphors }\end{array}$ & $\begin{array}{l}\text { - Information Processing } \\
\text { - Information Processing }\end{array}$ & $\begin{array}{l}\text { - Cognitive } \\
\text { - Cognitive }\end{array}$ \\
\hline $\begin{array}{l}\text { Summarizing and } \\
\text { note taking }\end{array}$ & $\begin{array}{l}\text { Summarizing and } \\
\text { note taking }\end{array}$ & - Information Processing & Cognitive \\
\hline $\begin{array}{l}\text { Reinforcing effort } \\
\text { and providing } \\
\text { recognition }\end{array}$ & $\begin{array}{l}\text { - Tutor giving feedback } \\
\text { - Tutor giving praise } \\
\text { - Student giving } \\
\text { - feedback } \\
\text { - Student giving praise }\end{array}$ & $\begin{array}{l}\text { - Process Monitoring + } \\
\text { Self } \\
\text { - Process Monitoring + } \\
\text { Self }\end{array}$ & $\begin{array}{l}\text { - Meta-Cognitive } \\
\text { - Self-System }\end{array}$ \\
\hline $\begin{array}{l}\text { Homework and } \\
\text { practice }\end{array}$ & $\begin{array}{l}\text { - Homework and } \\
\text { practice } \\
\text { - Reflections on } \\
\text { objectives } \\
\text { - Tutor assign group } \\
\text { work } \\
\text { - Students addition to } \\
\text { the argument }\end{array}$ & $\begin{array}{l}\text { - Use of knowledge } \\
\text { - Purpose } \\
\text { - Use of knowledge }\end{array}$ & $\begin{array}{l}\text { - Cognitive } \\
\text { - Self-System } \\
\text { - Cognitive }\end{array}$ \\
\hline $\begin{array}{l}\text { Nonlinguistic } \\
\text { representations }\end{array}$ & $\begin{array}{l}\text { Non-Linguistic } \\
\text { Presentation }\end{array}$ & - Input/Output & Cognitive \\
\hline Cooperative learning & $\begin{array}{l}\text { - Students providing } \\
\text { each other feedback } \\
\text { - Students share } \\
\text { information } \\
\text { - Students help one } \\
\text { another } \\
\text { - Students adding to } \\
\text { each other argument } \\
\text { - Students asking } \\
\text { questions } \\
\text { - Students recall of } \\
\text { previous knowledge/ } \\
\text { information } \\
\text { - Tutor assigning group } \\
\text { work } \\
\text { - Tutor recall of } \\
\text { pervious knowledge/ } \\
\text { information } \\
\text { - Tutor addition to the } \\
\text { argument } \\
\text { - Tutor addition to the } \\
\text { content }\end{array}$ & $\begin{array}{l}\text { - Process monitoring } \\
\text { - Information Processing } \\
\text { - Uslaboration } \\
\text { - Storage and Retrieval } \\
\text { - Storage and Retrieval + } \\
\text { - Use of Knowledge } \\
\text { - Collaboration } \\
\text { - Storage and Retrieval + } \\
\text { - Use of Knowledge } \\
\text { - Disposition } \\
\text { - Monitoring }\end{array}$ & $\begin{array}{l}\text { - Metacognitive } \\
\text { - Cognitive } \\
\text { - Metacognitive } \\
\text { and self } \\
\text { - Knowledge/ } \\
\text { Cognitive } \\
\text { - Cognitive } \\
\text { - Cognitive } \\
\text { - Knowledge/ } \\
\text { Cognitive } \\
\text { - Cognitive } \\
\text { - Metacognitive } \\
\text { and self } \\
\text { - Cognitive } \\
\text { - Meta-Cognitive } \\
\text { - Cognitive }\end{array}$ \\
\hline
\end{tabular}


Table 1. Continued

\begin{tabular}{|c|c|c|c|}
\hline $\begin{array}{l}\text { Clusters according } \\
\text { to Marzano's } 9\end{array}$ & $\begin{array}{c}\text { The } 29 \text { pedagogic } \\
\text { behaviours }\end{array}$ & Type & Theoretical backing \\
\hline $\begin{array}{l}\text { Setting objectives } \\
\text { and providing } \\
\text { feedback }\end{array}$ & $\begin{array}{l}\text { Tutor setting } \\
\text { objectives } \\
\text { - Tutor giving } \\
\text { directions } \\
\text { - Tutor giving } \\
\text { instructions } \\
\text { - Tutor giving updates } \\
\text { - Tutor addition to the } \\
\text { content } \\
\text { - Tutor giving students } \\
\text { feedback on progress } \\
\text { - Tutor praising } \\
\text { students } \\
\text { - Tutor adding to the } \\
\text { argument }\end{array}$ & $\begin{array}{l}\text { - } \text { Disposition } \\
\text { Monitoring } \\
\text { - Process Specification } \\
\text { - Process Specification } \\
\text { - Information Processing } \\
\text { - Information Processing } \\
\text { - Process Monitoring + } \\
\text { - Self } \\
\text { - Self } \\
\text { - Disposition } \\
\text { Monitoring }\end{array}$ & $\begin{array}{l}\text { - Meta-Cognitive } \\
\text { - Metacognitive } \\
\text { - Metacognitive } \\
\text { - Cognitive } \\
\text { - Metacognitive } \\
\text { - Metacognitive }\end{array}$ \\
\hline $\begin{array}{l}\text { Generating and } \\
\text { testing hypotheses }\end{array}$ & $\begin{array}{l}\text { - Students setting } \\
\text { hypotheses } \\
\text { - Students testing } \\
\text { hypotheses }\end{array}$ & $\begin{array}{l}\text { Disposition } \\
\text { Monitoring } \\
\text { - Disposition } \\
\text { Monitoring }\end{array}$ & - Meta-Cognitive \\
\hline $\begin{array}{l}\text { Activating prior } \\
\text { knowledge } \\
\text { (questions, hints or } \\
\text { cues) }\end{array}$ & $\begin{array}{l}\text { Tutor recall of } \\
\text { pervious knowledge/ } \\
\text { information } \\
\text { Tutor giving hints } \\
\text { - Tutor asking } \\
\text { questions } \\
\text { - Students recall of } \\
\text { previous knowledge/ } \\
\text { information }\end{array}$ & $\begin{array}{l}\text { - Storage and Retrieval } \\
\text { - Storage and Retrieval } \\
\text { - Storage and Retrieval } \\
\text { - Storage and Retrieval }\end{array}$ & $\begin{array}{l}\text { - Knowledge } \\
\text { - Cognitive }\end{array}$ \\
\hline
\end{tabular}

- Cooperative Learning (with a correlation of $\left.r(\mathrm{df}=138)=.375^{\star \star}, p<0.001\right)$.

- Setting Goals and Providing Feedback (with a correlation of $r(\mathrm{df}=138)=.328^{\star \star}$, $p<0.002$ ).

- Generating and testing hypotheses (with a correlation of $r(\mathrm{df}=138)=.431^{\star \star}, p$ $<0.001)$.

The total frequencies for all 29 pedagogic behaviours also showed a strong and positive correlation of $r(\mathrm{df}=138)=.328^{\star \star}, p<0.001$.

The two clusters (similarities and differences) and (recalling prior knowledge by giving hints and cues) didn't show any correlations with students' grades. Interestingly, this last cluster had had strong and positive correlations with the clusters feedbacks, homework, and cooperative learning which all showed significant correlation with grades. Analysis also revealed that tutors have to be more specific in giving their hints and cues; otherwise students get confused and wouldn't take them into consideration. 
Table 2. Comparison of effect sizes

\begin{tabular}{lll}
\hline Small effect sizes & Medium effect sizes & Large effect sizes \\
\hline $\begin{array}{l}\text { Similarities and differences } \\
(\mathrm{ES}=0.24)\end{array}$ & $\begin{array}{l}\text { Cooperative learning } \\
(\mathrm{ES}=0.53)\end{array}$ & $\begin{array}{l}\text { Summarizing and note } \\
\text { taking }(\mathrm{ES}=0.78)\end{array}$ \\
$\begin{array}{l}\text { Recognizing effort and feedback } \\
(\mathrm{ES}=0.3)\end{array}$ & $\begin{array}{l}\text { Setting objectives } \\
(\mathrm{ES}=0.50)\end{array}$ & $\begin{array}{l}\text { Non-linguistic } \\
\text { presentations }(\mathrm{ES}=0.79)\end{array}$ \\
$\begin{array}{l}\text { Generating and testing hypotheses } \\
(\mathrm{ES}=0.2)\end{array}$ & & $\begin{array}{l}\text { Homework and practice } \\
(\mathrm{ES}=0.83)\end{array}$ \\
& & $\begin{array}{l}\text { Recall of prior knowledge } \\
\text { or the use of questions and } \\
\text { cues }(\mathrm{ES}=0.76)\end{array}$ \\
\hline
\end{tabular}

Effect Size (ES) calculations were calculated for these nine clusters between two groups and were grouped according to Cohen's (1988) ranking of effect sizes (Table 2, $(N=62)$ ).

Although the effect size calculations provided useful information, it was not the sole basis for making judgement results. The total context of the study was taken into consideration, especially the measures that were used and the scores generated.

Following Cohen's interpretation of ES into percentile standing, the following could be expected as percentile gain from the calculated ES. In other words, the group of students that uses these clusters are likely to have better standing than those students who do not use them (Table 3).

The evidence suggests that these clusters are likely to increase students' grades and it was therefore of interest to analyze the relationship among these clusters and detect if there were any gender difference. School-based gender studies show the boys trail behind girls with their homework and school responsibilities (Sommers, 2000). Sukhnandan et al. (2000) even proposed rationales and recommendations to adopt certain

Table 3. Effect sizes and percentile standing

\begin{tabular}{lcc}
\hline Pedagogies & Effect size observed Cohen's $d$ & Percentile standing \\
\hline Similarities and differences & 0.24 & 58 \\
Summarizing and note taking & 0.78 & 79 \\
Reinforcing effort and providing feedback & 0.3 & 62 \\
Homework and practice & 0.83 & 79 \\
Non-lnguistic presentation & 0.79 & 79 \\
Cooperative learning & 0.53 & 69 \\
Setting objectives & 0.50 & 69 \\
Generating and testing hypotheses & 0.2 & 58 \\
Questions and cues & 0.76 & 79 \\
\hline
\end{tabular}


Table 4. Test statistics ${ }^{a}$

\begin{tabular}{lrrrrrrr}
\hline & $\begin{array}{c}\text { Summarising } \\
\text { \& Note } \\
\text { Takin }\end{array}$ & $\begin{array}{c}\text { Reinforcing } \\
\text { Efforts \& } \\
\text { Recognition }\end{array}$ & Homework & Nonling & \multicolumn{4}{c}{$\begin{array}{c}\text { Cooperating } \\
\text { Learning }\end{array}$} & Fbjectives \& \\
& Feedbacks & Hypotheses \\
\hline Mann- & 733.500 & 822.500 & 720.000 & 741.500 & 819.500 & 861.000 & 694.500 \\
Whitney U & & & & & & & \\
Wilcoxon W & 838.500 & 8697.500 & 825.000 & 8616.500 & 924.500 & 8736.000 & 799.500 \\
Z & -.990 & -.367 & -1.085 & -.971 & -.342 & -.098 & -1.263 \\
Asymp. Sig. & .322 & .713 & .278 & .331 & .732 & .922 & .206 \\
(2-tailed) & & & & & & & \\
\hline
\end{tabular}

a. Grouping Variable: GENDER

pedagogic strategies that address gender differences in achievement. Due to the fact that the number of male enrolled in these programmes has drastically surpassed the female, non-parametric tests were conducted (Table 4).

The three tests Mann-Whitney, Wilcoxon and Wald-Wolfowitz showed no significant difference. Therefore, we could firmly conclude that the use of these specific clusters of pedagogies within our context is gender-neutral (Figure 2).

The same was applicable for the two remaining clusters and no difference was found (Figure 3). Therefore the use of e-learning pedagogies within our context appears to be gender-neutral.

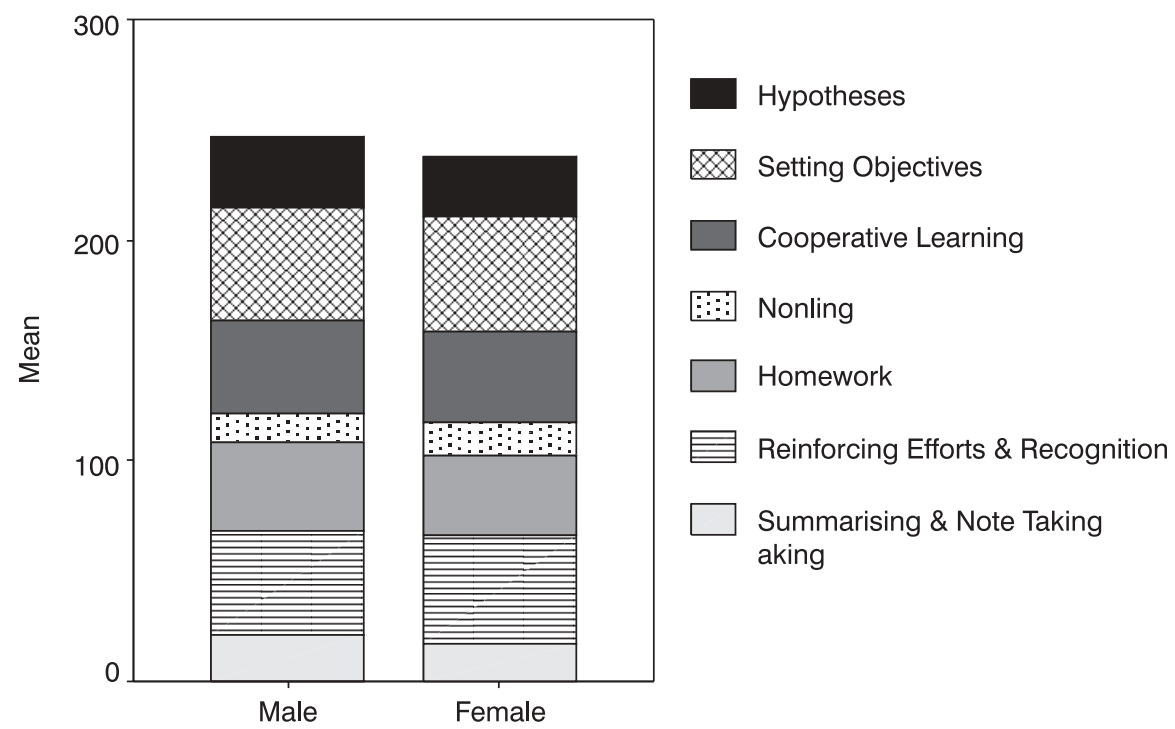

GENDER

Figure 2. Gender comparison 


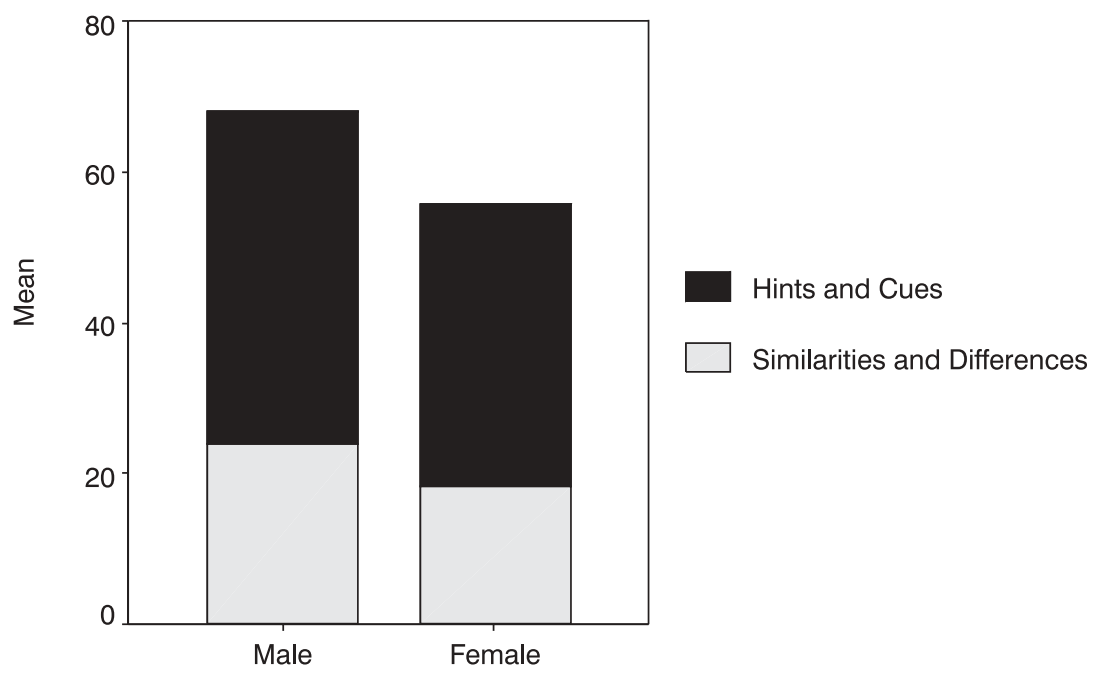

GENDER

Figure 3. Comparison across genders

\section{Validation of the effect size calculations}

Royer (2000) warned: 'It is important to note that measures of effect sizes do not directly translate into indications of practical importance' (p. 239). This warning reinforces earlier work by Glass et al. (1981) where they specified that it was not enough to associate the effect-size metric with descriptive adjectives such as 'small, moderate and large'. Therefore, determining the significance of a particular effect size requires interpreting what the size of the effect really means. While recent recommendations (Wainer \& Robinson, 2003) were made for the Null Hypothesis (NH) to support the calculation of the effect size and determining its practical importance, it was found that this is not applicable in all cases and several criticisms were apparent due to the misuse and misinterpretation of the NS (Cohen, 1990, 1994; Rosenthal, 1991; Thompson, 1994). An alternative for interpreting the value of ES or its educational significance is 'to think meta-analytically' (Thompson, 2002). Thompson prefers a model where effect sizes from individual studies are interpreted in the context of previous studies, let alone a meta-analysis in our case. This was an additional incentive behind the regrouping of the 29 pedagogic behaviours into Marzano's original 9. The mean and the median indicated non-symmetry in both sets of data, Marzano's and Mehanna's (ES); therefore, the sign test, a binomial test, was found to be the most suitable to seek further comparisons and interpretations (Table 5).

No significant difference was observed. This indicates that the average effect size produced by the different clusters of pedagogies of this study generated almost the same statistical effect reported in Marzano's meta-analysis. 
Table 5. Test statistics ${ }^{\mathrm{a}}$

\begin{tabular}{lc}
\hline & MEHANNA - MARZANO \\
\hline Exact Sig. (2-tailed) & $.180^{b}$ \\
\hline${ }^{a}$ Sign test. \\
${ }^{b}$ Binomial distribution used.
\end{tabular}

\section{Conclusion and implications}

This mixed methods multi-case study research has purposely focused on the pedagogic aspect of e-learning in higher education. Findings suggest a number of pedagogies that are worthy of including in the online teaching and learning processes due to their theoretical backing and the empirical evidence of their correlations with students' learning and outcomes. These emerging nine clusters of pedagogies represent a composite system made of 29 effective practices belonging to four learning systems. These findings provided empirical evidence that 'blending' different learning theories and pedagogies was not only possible but beneficial, and satisfied Oliver's (2004) call to justify the use of 'blended pedagogies'.

The pedagogically driven approach to e-learning allows practitioners to make the link between pedagogy and different learning systems (Conole et al., 2004). This in turn provides empirical evidence that confirms Minocha and Sharp (2004) proposition which denotes that 'e-learning in higher education should adopt pedagogical models that are not fundamentalist in nature but allow for a complementarity between behaviourism and constructivism' (p. 2) and cognitivism (Driscoll, 2002). 'One reason for the lack of application of models and theories by e-learning practitioners may be that, as academics outside the field of education, they find the diverse array of theoretical perspectives alien and overwhelming' (Conole et. al, 2004, p. 18; McNaught, 2003).

Adopting the effective pedagogies presented in this study seems a first step towards preparing e-pedagogues. An e-pedagogue is a teacher at heart, has a passion for learning, knowledge of learning theories and effective pedagogy, and understands the functionality of e-learning technology.

\section{Acknowledgments}

The author wishes to thank John Siraj-Blatchford for the personal interest he showed, the enthusiasm with which he supervised the PhD work, and for his insightful professional guidance. Another note of gratitude goes to those who gave me access to their courses and to the students who took part in this study.

\section{References}

Alexander, S. \& Boud, D. (2001) Learners still learn from experience when online, in: J. Stephenson (Ed.) Teaching and learning online: pedagogies for new technologies (London, Kogan Page). 
Ajzen, I. (1985) From intentions to actions: a theory of planned behavior, in: J. Kuhl \& J. Beckmann (Eds) Action-control: from cognition to behavior (Heidelberg, Springer), 11-39.

Ajzen, I. \& Fishbein, M. (1977) Attitude-behavior relations: a theoretical analysis and review of empirical research, Psychological Bulletin, 84, 888-918.

Ajzen, I. \& Fishbein, M. (1980) Understanding attitudes and predicting social behaviour, (Englewood Cliffs, NJ, Prentice-Hall, Inc.).

Anderson, J. A. (1995) An introduction to neural networks (Cambridge, MA, MIT Press).

Brown, A. I. (1978) Knowing when, where, and how to remember: a problem of metacognition, in: R. Glaser (Ed.) Advances in instructional psychology (New York, Halstead Press).

Brown, A. (1987) Metacognition, executive control, self-regulation, and other mysterious mechanisms, in: F. E. Weinert \& R. H. Kluwe (Eds) Metacognition, motivation, and understanding (Hillsdale, NJ, Lawrence Erlbaum Associates), 65-116.

Bruner, J. (1997a) Toward a theory of instruction (Cambridge, MA, The Belknap Press of Harvard University Press).

Bruner, J. (1997b) The culture of education (Cambridge, MA, Harvard University Press).

Cohen, J. (1988) Statistical power analysis for the behavioral sciences (2nd edn) (Hillsdale, NJ, Erlbaum).

Cohen, J. (1990) Things I have learned (so far), American Psychologist, 49, 997-1003.

Cohen, J. (1994) The earth is round ( $p<0.5)$, American Psychologist, 45, 1304-1312.

Conole, G., Dyke, M., Oliver, M. \& Seale, J. (2004) Mapping pedagogy and tools for effective learning, Computers and Education, 43, 17-33.

Coomey, M. \& Stephenson, J. (2001) Online learning: it is all about dialogue, involvement, support and control-according to the research, in: J. Stephenson (Ed.) Teaching and learning online: pedagogies for new technologies (London, Kogan Page).

Creswell, J. W. (2003) Research design: qualitative, quantitative, and mixed methods approaches, (2nd edn) (London, Sage).

Crook, C. K. (1994) Computers and the collaborative experience of learning (London, Routledge).

Driscoll, M. (2002) Blended learning: let's go beyond the hype, E-learning, 1 March.

Flavell, J. H. (1979) Metacognition and cognitive monitoring: a new area of cognitive-developmental inquiry, American Psychologist, 34, 906-911.

Flavell, J. H. (1987) Speculations about the nature and development of metacognition, in: F. E. Weinert \& R. H. Kluwe (Eds) Metacognition, motivation and understanding (Hillside, NJ, Lawrence Erlbaum Associates), 21-29.

Gagne, R. M. (1965) The conditions of learning (New York, Holt, Rinehart \& Winston Inc.).

Garcia, T. (1995) The role of motivational strategies in self-regulated learning, in: P. R. Pintrich (Ed.) Understanding self-regulated learning (San Francisco, CA, Jossey-Bass).

Garcia, T. \& Pintrich, P. R. (1991) Students' motivation and self-regulated learning: a LISREL model, paper presented at the Annual meeting of AERA, Chicago. (ERIC Document No: ED 333006).

Garcia, T. \& Pintrich, P. R. (1993) Self schemas, motivational strategies and self-regulated learning, paper presented at the Annual meeting of AERA, Atlanta (ERIC Document No: ED 359234).

Glass, G. V., McCaw, B. \& Smith, M. L. (1981) Meta-analysis in social research (Beverly Hills, CA, Sage).

Goodyear, P. (1995) Asynchronous peer interaction in distance education: the evolution of goals, practices, and technology, Training Research fournal, 1, 71-102.

Goodyear, P. (2001) Psychological foundations of networked learning, in: C. Jones \& C. Steeples (Eds) Networked learning: perspectives and issues (Godalming, Springer).

Goodyear, P. (2002) Effective networked learning in higher education: notes and guidelines. JCALT Project, Volume 3 of the Final Report to JCALT, Lancaster UK

Hara, N., Bonk, C. J. \& Angeli, C. (2000) Content analysis of online discussion in an applied educational psychology course, Instructional Science, 28, 115-152. 
Harter, S. (1980) The perceived competence scale for children, Child Development, 51, 218-235.

Hattie, J., Biggs, H. \& Purdie, N. (1996) Effects of learning skills interventions on student learning: a meta-analysis. Review of Educational Research, 66(2), 99-136.

Henri, F. (1997) Computer conferencing and content analysis, in: A. R. Kaye (Ed.) collaborative learning through computer conferencing: the Najaden papers (New York, Springer-Verlag), 115-136.

Laurillard, D. (1993) Rethinking university teaching (London, Routledge).

Laurillard, D. (1997) Learning formal representations through multimedia, in: N. Entwistle (Ed.) The experience of learning (London, Academic Press).

Laurillard, D. (2002) Design tools for e-learning (Department for Education and Skills, UK).

Laurillard, D. \& McAndrew (2003) Reusable educational generic software: a basis for generic learning activities, in: A. Littlejohn (Ed.) Reusing online resources: a sustainable approach to e-learning (London, Kogan Page).

Lindsey, P. H. \& Norma, D. A. (1977) Human information processing (New York, Academic Press).

Lipsey, M. \& Wilson, D. (2001) Practical meta-analysis (London, Sage).

Markus, H. \& Ruvulo, A. (1990) Possible selves. Personalized representations of goals, in: L. Pervin (Ed.) Goal concepts in psychology (Hillsdale, NJ, Lawrence Erlbaum), 211-241.

Marzano, R. (1998) A theory-based meta-analysis of research on instructions (Office of Educational Research and Improvement (OERI), US Department of Education).

Marzano, R. (2000) What works in classroom instructions (USA, Mid-Continent Research For Education and Learning).

Marzano, R. (2001) Analyzing two assumptions underlying the scoring of classroom assessments, in: SuDoc (ED 1.310/2:447169).

Marzano, R. J., Pickering, D. J. \& Pollock, J. E. (2001) Classroom instruction that works: researchbased strategies for increasing student achievement (Alexandria, VA, Association for Supervision and Curriculum Development).

McNaught, C. (2003) The effectiveness of institution-wide mentoring programmes for improving online teaching and learning, fournal of Computing in Higher Education, 15(1), 27-45.

Mehanna, W. (2002) A case study of interactions with, attitudes to, and perceptions of online learning, Unpublished M.Phil. Thesis, University of Cambridge.

Mehanna, W. (2004) A case study of interactions with, attitudes to, and perceptions of online learning, In Technology and education (Ed.). LAES.

Minocha, S. \& Sharp, H. (2004) Learner-centered design and evaluation of Web-based environments (Buckingham, Open University Press). Available online at: http://www.ics.ltsn.ac.uk/pub/ HCI2004/MinochaandSharp2004.pdf (accessed June 2004).

Mortimore, P. (1999) Understanding pedagogy and its impact on learning (London, Paul Chapman).

Oliver, M. (2004) Against the term 'Blended Learning'. Available online at: http://kn.open.ac.uk/ public/getfile.cfm?documentfileid=4876 (Accessed June 2004).

Rosenthal, R. (1991) Meta-analysis procedures for social research (Thousands Oaks, CA, Sage).

Royer, J. M. (2000) Editorial: a policy on reporting of effect sizes, Contemporary Educational Psychology, 25, 239.

Salmon, G. (2000) E-Moderating: the key to teaching and learning online (London, Kogan Page).

Schank, R. C. \& Abelson, R. (1977) Scripts, plans, goals, and understanding (Hillsdale, NJ, Erlbaum Association).

Schon, D. (1992) Educating the reflective practitioner: towards a new design for teaching and learning in the professions (London, Jossey-Bass).

Spector, J. M. (2002) Foreword, in: C. Steeples \& C. Jones (Eds) Networked learning: perspectives and issues (London, Springer-Verlag).

Stake, R. (2000) Case studies, in: N. Denzin \& Y. Lincoln (Eds) Handbook of qualitative research (New York, Sage Publications).

Steeples, C. \& Jones, C. (Eds) (2002) Networked learning: perspectives and issues (London, SpringerVerlag). 
Stephenson, J. (2002) Teaching and learning online: pedagogies for new technologies (London, Kogan Page).

Stephenson, J. (2002) Learner managed learning: an emerging pedagogy for online learning? The fournal of the World Education Fellowship, 83(3), 81-82.

Sternberg, R. J. (1978) Toward a unified componential theory of human reasoning (New Haven, CT, Yale University).

Sternberg, R. J. (1979) The development of human intelligence (New Haven, CT, Yale University).

Sternberg, R. J. (1984) What should intelligence test test? Implications of a triarchic theory of intelligence for intelligence testing, Educational Researcher (January), 5-15.

Sternberg, R. J. (1986) Beyond IQ: a triarchic theory of human intelligence (New Haven, CT, Yale University Press).

Sternberg, R. J. (1986a) Inside intelligence, American Scientist, 74, 137-143.

Sternberg, R. J. (1986b) Intelligence applied (New York, Harcourt Brace Jovanovich Publishers).

Strauss, A. \& Corbin, V. (1998) Basics of qualitative research. Techniques and procedures for developing grounded theory (London, Sage).

Thompson, B. (1994) The concept of statistical significance (Report No. EDO-TM-94-1) (Washington, DC, Office of Educational Research and Improvement).

Thompson, B. (2002) What future social science research should look like: confidence interval for effect sizes, Educational Researcher, 31(3), 24-31.

Valdez, G., McNabb, M., Foertsch, M., Anderson, M., Hawkes, M. \& Raack, L. (2000) Computer-based technology and learning: evolving uses and expectations. Available online at: http://www.ncrel.org/tplan/cbtl/toc.htm (accessed June 2003).

Wainer, H. \& Robinson, D. (2003) Shaping up the practice of the null hypothesis significance test, American educational Research Association, 3. 